\title{
Paramedik Öğrencilerinin Biyoterörizm İle Biyolojik Ajanlara İlişkin Bilgi ve Görüşlerinin İncelenmesi*
}

\author{
Hatice DEMİRAĞ ${ }^{1}$, Sevilay HINTISTAN ${ }^{2}{ }^{2}$, Esin SEVGİ DOĞ $\breve{A N}^{3}$, \\ Aynur CIN ${ }^{1}$, Birgül TUNCAY 國
}

ÖZ

Amaç: $\mathrm{Bu}$ araştırmanın amacı, paramedik öğrencilerinin biyoterörizm ve biyolojik ajanlar konusundaki bilgi ve görüşlerini incelemektir.

Gereç ve Yöntemler: Tanımlayıcı olarak yapılan bu araştırma Mayıs-Haziran 2018 tarihleri arasında gerçekleştirildi. Araştırmanın evrenini, Gümüşhane Üniversitesi Kelkit Sağlık Hizmetleri Meslek Yüksekokulu İlk ve Acil Yardım Programı öğrencileri ( $\mathrm{n}=200)$ oluşturdu. Çalışma anketini doldurmayı kabul eden 164 öğrenci ile çalışma yürütüldü. Veriler, araştırmacılar tarafından oluşturulan "katılımcıların tanıtıı bilgileri" ve "katılımcıların biyoterörizm ve biyolojik ajanlara ilişkin bilgi ve görüşleri”" anket formu ile toplandı. Verilerin değerlendirilmesinde tanımlayıcı istatistikler (ortalama, standart sapma, minimum ve maksimum, yüzdelik dağılımlar) ve Pearson Chi-square testi kullanıldi.

Bulgular: Araştırmaya katılan paramedik adayların \%51.8'inin kadın, yaş ortalamasının $19.99 \pm 1.12$ (Min:18Maks:24), \%56.1'inin birinci sınıf öğrencisi, \%50.6'sının sağlık meslek lisesi mezunu, \%47’sinin şehirde yaşadığı, \%48.2'sinin gelirinin giderine denk olduğu belirlendi. Öğrencilerin, yaklaşık yarısının (\%55.5) biyoterörizme ilişkin eğitim almak istedikleri, büyük bir çoğunluğunun (\%69.5) biyoterörizme karşı paramediklerin rol ve sorumlulukları bildikleri tespit edildi. Ayrıca, öğrencilerin sadece \%37.8'inin biyolojik ajanların saptanmasının güç olduğunu ve duyularla anlaşılamayacağını bildikleri belirlendi.

Sonuç: Öğrencilerin büyük bir çoğunluğunun (\%69.5) biyoterörizme karşı paramediklerin rol ve sorumlulukları bilmelerine karşı, biyoterörizm ile biyolojik ajanlara ilişkin bilgi düzeyleri istenen düzeyde değildi. Elde edilen bulgular doğrultusunda, paramedik adaylarına eğitim-öğretim süreçlerinde belli periyotlarda biyoterörizm ve biyolojik ajanlara ilişkin eğitim ve tatbikat planlaması yapıldı.

Anahtar Kelimeler: Paramedik; biyoterörizm; biyolojik savaş ajanları.

\section{Examination of the Information and Opinions of Paramedic Students on Bioterrorism and Biological Agents}

\begin{abstract}
Aim: The aim of this research is to examine the information and opinions of paramedic students about bioterrorism and biological agents.

Material and Methods: This study was conducted between May and June 2018 that be made descriptive. The universe of the research was the First and Emergency Program students $(n=200)$ of Gümüşhane University Kelkit Health Services Vocational School. Study was conducted with 164 students who agreed to fill out the study questionnaire. The data were collected by means of the "participant's introductory information" and "participant's knowledge and opinions on bioterrorism and biological agents" questionnaire which are created by participants. Descriptive statistics (mean, standard deviation, minimum and maximum, percentage distributions) and Pearson Chi-square test were used in the evaluation of the data.

Results: It was determined that $51.8 \%$ of the paramedic candidates participating in the survey were female, mean age was $19.99 \pm 1.12$ (Min: 18-Max: 24), 56.1\% of them were first-year students, $50.6 \%$ of them were health vocational

1 Gümüşhane Üniversitesi, Kelkit Sağlık Hizmetleri Meslek Yüksekokulu, Tıbbi Hizmetler ve Teknikler Bölümü, İlk ve Acil Yardım Pr., Gümüşhane, Türkiye 2 Karadeniz Teknik Üniversitesi, Sağlık Bilimleri Fakültesi, Hemşirelik Bölümü, İç Hastalıkları A.D., Trabzon, Türkiye

3 Celal Bayar Üniversitesi, Sağlık Bilimleri Fakültesi, Hemşirelik Bölümü, İç Hastalıkları A.D., Manisa, Türkiye

4 Gümüşhane Üniversitesi, Kelkit Sağlık Hizmetleri Meslek Yüksekokulu, Çocuk Bakımı ve Gençlik Hizmetleri Bölümü, Çocuk Gelişimi Pr., Gümüşhane, Türkiye

*Bu çalışma, 22-24 Ekim 2018 tarihleri arasında Gümüşhane'de düzenlenen 1.Uluslararası Afet Yönetimi-IDMC 2018 Kongresinde sözlü bildiri olarak sunulmuştur.


high school graduates, and $47 \%$ of them lived in the city, $48.2 \%$ is equivalent to the expense of the income. It was determined that approximately half of the students (55.5\%) wanted to have education about bioterrorism, and the majority (69.5\%) knew the roles and responsibilities of the paramedics against bioterrorism. In addition, it was determined that only $37.8 \%$ of the students knew that the detection of biological agents was difficult and could not be understood by the senses.

Conclusion: While the majority of the students (69.5\%) knew the roles and responsibilities of the paramedics against bioterrorism, their knowledge of bioterrorism and biological agents was not at the desired level. In line with the findings obtained, training and exercise planning were conducted for paramedic candidates on bioterrorism and biological agents at certain periods in the educationteaching processes.

Keywords: Paramedic; bioterrorism; biological warfare agents.

\section{GíRiş}

Biyoterörizm; biyolojik ajanların canlılar üzerinde ölüme neden olmak, kargaşa yaratmak ve hastalık oluşturmak gibi amaçlarla terör veya savaş amacı taşıyan kişi veya gruplar tarafından kullanımıdır $(1,2)$. Biyolojik savaş ajanları ise "savaşlarda ve/veya ayaklanmalarda kaos yaratmak, halkı paniğe sürüklemek için kullanılan, mortalite ve/veya morbiditeye neden olabilen biyolojik kökenli kitle imha silahları" olarak tanımlanabilir (3). Biyolojik savaş ajanları, silah yapımında kullanılarak insan ve hayvan sağlığı için tehdit oluşturabilen, nesnelerin kontaminasyonuna neden olabilen mikroorganizma ile biyolojik kökenli toksinler biyolojik ajan olarak ifade edilir. Kitle imha silahları arasında sayabileceğimiz biyolojik savaş ajanları, hastalık yaptığ ve çok kısa bir sürede büyük kitlelere yayılabildiği için mikroorganizmalarla büyük tehlikelere neden olabilmektedir (2,3).

Ulusal ve uluslararası, politik, ideolojik ve ekonomik alanlarda gerçekleştirilmesi muhtemel terörist faaliyetler tüm dünya ülkelerinde gündem konularındandır. Kolay ve ucuza üretilebilmeleri, kolay ve maliyetsiz taşınabilmeleri, hızlı bir şekilde geniş alanlara yayılabilmeleri, iz bırakmamaları sinsi bir şekilde yayılım göstermeleri ve dış etkenlere karşı dayanıklılıkları biyolojik silahların avantajlarıdır. Bu özellikleri ile biyolojik silahlar; terör gruplarının ve çevrelerinin odak noktası haline gelmiştir (2).

Biyolojik ajana maruziyet sonucunda ciddi bir şekilde yaralanmış kişilerin, zamanında ve uygun acil müdahale yapıldığında, tamamen iyileşme şansları yüksektir. Bu nedenle acil sağlık hizmeti sunacak sağlık personeli (paramedik) ile hastane acil servislerinin biyoterörizm olaylarına hazırlıklı olması, ajanı tanıması ve ajandan korunması oldukça önemlidir (4).

Acil tıp teknikerlerinin ve acil çalışanlarının müdahalede bulundukları kişinin biyolojik savaş ajanına maruz kalıp kalmadığını anlamak, belli ipuçlarını tanımak ve biyolojik ajanı arındırmak (temizlemek) konusunda eğitimli olması gereklidir (4-6). Bu nedenle bu çalışmada, paramedik öğrencilerinin biyoterörizm ve biyolojik ajanlara ilişkin bilgi ve görüşlerinin incelenmesi amaçlanmıştır.

\section{GEREÇ VE YÖNTEMLER}

\section{Araştırmanın Amacı ve Tipi}

Araştırma, paramedik öğrencilerinin biyoterörizm ve biyolojik ajanlara ilişkin bilgi ve görüşlerini incelemek amacı ile tanımlayıcı tipte yapılmıştır.

\section{Araştırmanın Evreni ve Örneklemi}

Araştırmanın evrenini, Mayıs-Haziran 2018 tarihleri arasında Gümüşhane Üniversitesi Kelkit Sağlık Hizmetleri Meslek Yüksekokulu İlk ve Acil Yardım Programında eğitim gören üniversite öğrencileri $(n=200)$ oluşturdu. Araştırmada örneklem seçimine gidilmemiş evrenin tamamı çalışmaya dahil edilmiştir. Çalışmaya katılmayı gönüllü olarak kabul eden 164 öğrenci ile çalışma tamamlanmıştır.

\section{Araştırmaya Dahil Edilme Ölçütleri}

İlk ve Acil Yardım Programı öğrencisi olmak, araştırmaya katılmayı kabul etmek araştırmaya dahil edilme ölçütleri olarak belirlendi.

\section{Veri Toplama Araçları}

Araştırma verileri, "kişisel bilgi formu" ve "biyoterörizm ve biyolojik ajanlar hakkında bilgi ve görüş formu" kullanılarak toplandı. Kişisel bilgi formu; öğrencilerin tanıtıcı bilgilerini (yaş, cinsiyet, sınıf, öğrenim grubu, yaşanılan yer, mezun olunan lise ve gelir algı durumu) belirlemeye yönelik yedi soru içermektedir. Biyoterörizm ve biyolojik ajanlar hakkında bilgi ve görüş formu; araştırmacılar tarafından literatür taranarak oluşturulan, öğrencilerin biyoterörizm ve biyolojik ajanlar konusundaki bilgi ve görüşlerini (biyoterörizm ile ilgili eğitim alıp almadıkları, biyoterörizm hakkında ne bildikleri, biyolojik ajanların etkileri, özellikleri, temizlenmesi gibi) belirlemeye yönelik 32 sorudan oluşmaktadır.

\section{Veri Toplama Yöntemi}

Anket formu, sınıf ortamında araştırmacılar tarafindan yüz yüze görüşme tekniği kullanılarak uygulandı. Anket formunun doldurulması yaklaşık 15 dakika sürdü.

\section{Araştırmanın Etik Yönü}

Araştırmanın anket formunun dağıtılması sırasında; araştırmacılar tarafından araştırmaya katılan öğrencilere çalışma hakkında bilgi verilerek araştırmaya katılan öğrencilerden "sözlü onamı” alındı. Ayrıca, araştırmanın yapılabilmesi için gerekli etik kurul izni (2018/5 sayı ve 17/05/2018 tarihli) Gümüşhane Üniversitesi Etik Kurulu'ndan alındı. Araştırmanın yapıldığı Kelkit Sağlık Hizmetleri Meslek Yüksekokulu Müdürlüğü'nden (26/04/2018 tarihli ve 18562243-730.08.03-E.14054 sayılı) araştırmanın amaç ve kapsamını içeren bilgi formu sunularak gerekli yazılı kurum izni alındı.

\section{İstatistiksel Analiz}

Araştırma verileri, bilgisayar ortamında SPSS 18 paket programinda değerlendirildi. Verilerin değerlendirilmesinde; değişkenlerin türüne göre hesaplanan tanımlayıcı istatistiklerden (ortalama, standart sapma, minimum ve maksimum, yüzdelik dağılımlar) ve Pearson Chi-square testinden yararlanıldı. Önemlilik seviyesi $\mathrm{p}<0.05$ olarak alınd.

\section{BULGULAR}

Araştırma kapsamına alınan paramedik öğrencilerinin yaş ortalamasının $19.99 \pm 1.12$ (Min:18-Maks:24) olduğu, öğrencilerin \%51.8'inin kadın, \%56.1'inin birinci sınıf, \%56.1'inin birinci öğretim, \%50.6'sının Sağlık meslek 
lisesi mezunu, \%47'sinin şehirde yaşadığı ve \%48.2'sinin gelirinin giderine eşit olduğu belirlendi (Tablo 1).

Tablo 1. Öğrencilerin Tanıtıcı Özellikleri $(n=164)$

\begin{tabular}{|c|c|c|}
\hline \multirow{3}{*}{ Yaş } & \multicolumn{2}{|c|}{$\begin{array}{c}\text { Ortalama } \pm \text { Standart } \\
\text { Sapma }\end{array}$} \\
\hline & \multicolumn{2}{|c|}{$19.99 \pm 1.12$} \\
\hline & Sayı & Yüzde \\
\hline \multicolumn{3}{|l|}{ Cinsiyet } \\
\hline Kadın & 85 & 51.8 \\
\hline Erkek & 79 & 48.2 \\
\hline \multicolumn{3}{|l|}{ Sinıf } \\
\hline Birinci Sinıf & 92 & 56.1 \\
\hline İkinci Sınıf & 72 & 43.9 \\
\hline \multicolumn{3}{|l|}{ Öğrenim Grubu } \\
\hline Birinci Öğretim & 77 & 47.0 \\
\hline İkinci Öğretim & 87 & 53.0 \\
\hline \multicolumn{3}{|l|}{ Mezun Olunan Lise } \\
\hline Sağlık Meslek Lisesi & 83 & 50.6 \\
\hline Sağlık Dışında Bir Lise & 81 & 49.4 \\
\hline \multicolumn{3}{|l|}{ Yaşanılan Yer } \\
\hline Köy & 25 & 15.2 \\
\hline Kasaba-İlçe Merkezi & 62 & 37.8 \\
\hline Şehir & 77 & 47.0 \\
\hline \multicolumn{3}{|l|}{ Gelir Algı Durumu } \\
\hline Gelir $<$ Gider & 76 & 46.3 \\
\hline Gelir = Gider & 79 & 48.2 \\
\hline Gelir $>$ Gider & 9 & 5.5 \\
\hline
\end{tabular}

Araştırmaya katılan öğrencilerin \%45.1'i biyoterörizmin ne olduğunu bildiğini ve biyoterörizm konusunda daha önce eğitim aldığını, \%55.5'inin biyoterörizme ilişkin eğitim almak istediğini, \%60.4'ü biyoterörizme ilişkin Türkiye'nin risk taşıdığını, \%47.6'sı biyoterörizme ilişkin Türkiye'nin tehlike yaşaması ile ilgili fikrinin olmadığını, \%69.5'i biyoterörizmde paramediklerin rol ve sorumluluklarının bulunduğunu, \%64.6'sı biyoterörizmle saldırı için çalışan ülkelerin olduğunu ve \%37.2'si biyoterörizmle saldırı ihtimaline karşı ülkelerin önlem aldığını ifade etmişlerdir (Tablo 2).

Birinci sınıf öğrencilerinin \%52.2'si ile sağlık dışında bir liseden mezun olan öğrencilerin \%49.4'ü biyoterörizmi bilmektedir. Ancak biyoterörizmi bilme durumları ile öğrencilerin sinıfi $\left(\chi^{2}=4.583, \mathrm{p}=0.101\right)$ ve mezun oldukları lise $\left(\chi^{2}=4.560, p=0.102\right)$ arasında anlamlı bir ilişki saptanmadı ( $\mathrm{p}>0.05$, Tablo 3$)$.
Tablo 2. Öğrencilerin Biyoterörizme İlişkin Bilgi ve Görüșleri (n=164)

\begin{tabular}{|c|c|c|}
\hline & Sayı & Yüzde \\
\hline \multicolumn{3}{|c|}{ Biyoterörizmin ne olduğunu bilme } \\
\hline Evet & 74 & 45.1 \\
\hline Hayır & 33 & 20.1 \\
\hline Kismen & 52 & 31.7 \\
\hline Fikrim Yok & 5 & 3.0 \\
\hline \multicolumn{3}{|c|}{ Biyoterörizme ilişkin eğitim alma } \\
\hline Evet & 33 & 45.1 \\
\hline Hayır & 11 & 20.1 \\
\hline Kismen & 19 & 31.7 \\
\hline Fikrim Yok & 11 & 3.0 \\
\hline \multicolumn{3}{|c|}{$\begin{array}{l}\text { Biyoterörizme ilişkin eğitim almak } \\
\text { isteme }\end{array}$} \\
\hline Evet & 91 & 55.5 \\
\hline Hayır & 37 & 22.6 \\
\hline Kismen & 28 & 17.1 \\
\hline Fikrim Yok & 8 & 4.9 \\
\hline \multicolumn{3}{|c|}{$\begin{array}{l}\text { Biyoterörizme ilişkin Türkiye'nin risk } \\
\text { taşıma durumu }\end{array}$} \\
\hline Evet & 99 & 60.4 \\
\hline Hayır & 6 & 3.7 \\
\hline Kismen & 24 & 14.6 \\
\hline Fikrim Yok & 35 & 21.3 \\
\hline \multicolumn{3}{|c|}{$\begin{array}{l}\text { Biyoterörizme ilişkin Türkiye'nin } \\
\text { tehlike yaşama durumu }\end{array}$} \\
\hline Evet & 43 & 26.2 \\
\hline Hayır & 21 & 12.8 \\
\hline Kismen & 22 & 13.4 \\
\hline Fikrim Yok & 78 & 47.6 \\
\hline \multicolumn{3}{|c|}{$\begin{array}{l}\text { Biyoterörizmde paramediklerin rol ve } \\
\text { sorumluluklarının varlığı }\end{array}$} \\
\hline Evet & 114 & 69.5 \\
\hline Hayır & 1 & 0.6 \\
\hline Kismen & 25 & 15.2 \\
\hline Fikrim Yok & 24 & 14.6 \\
\hline \multicolumn{3}{|c|}{$\begin{array}{l}\text { Biyoterörizmle saldırmak için çalışan } \\
\text { ülkelerin varlığı }\end{array}$} \\
\hline Evet & 106 & 64.6 \\
\hline Hayır & 3 & 1.8 \\
\hline Kismen & 14 & 8.5 \\
\hline Fikrim Yok & 41 & 25.0 \\
\hline \multicolumn{3}{|c|}{$\begin{array}{l}\text { Biyoterörizmle saldırı ihtimaline karşı } \\
\text { ülkelerin önlem alma durumu }\end{array}$} \\
\hline Evet & 61 & 37.2 \\
\hline Hayır & 15 & 9.1 \\
\hline Kismen & 41 & 25.0 \\
\hline Fikrim Yok & 47 & 28.7 \\
\hline
\end{tabular}

Tablo 3. Öğrencilerin Sınıflarına ve Mezun Oldukları Liseye Göre Biyoterörizmi Bilme Durumları (n=164)

\begin{tabular}{|c|c|c|c|c|c|}
\hline & $\begin{array}{c}\text { Evet } \\
\text { n (\%) }\end{array}$ & $\begin{array}{c}\text { Hayır-Fikrim Yok } \\
\text { n (\%) }\end{array}$ & $\begin{array}{c}\text { Kismen } \\
\text { n (\%) }\end{array}$ & $\begin{array}{c}\text { Test } \\
\text { İstatistiği }\end{array}$ & $\mathbf{p}$ \\
\hline \multicolumn{6}{|l|}{ Sinıf } \\
\hline Birinci sinif & $48(52.2)$ & $20(21.7)$ & $24(26.1)$ & $4.583 *$ & 0.101 \\
\hline İkinci sınıf & $26(36.1)$ & $18(25.0)$ & $28(38.9)$ & & \\
\hline \multicolumn{6}{|l|}{ Mezun Olunan Lise } \\
\hline Sağlık Meslek Lisesi & $34(41.0)$ & $25(30.1)$ & $24(28.9)$ & & 0 \\
\hline Sağlık Dışında Bir Lise & $40(49.4)$ & $13(16.0)$ & $28(34.6)$ & $4.560^{*}$ & 2 \\
\hline
\end{tabular}


\%6.7’sinin “gazete-dergiden” ve \%39'unun “internethizmet içi eğitimden” öğrendikleri belirlendi (Tablo 4).

Tablo 4. Öğrencilerin Biyoterörizm Konusunda Bilgi Alma Durumu ( $\mathrm{n}=164)$

\begin{tabular}{|c|c|c|}
\hline & Sayı & Yüzde \\
\hline \multicolumn{3}{|c|}{ Okul-Dersler } \\
\hline Evet & 57 & 34.8 \\
\hline Hayır & 107 & 65.2 \\
\hline \multicolumn{3}{|c|}{ TV-Radyo } \\
\hline Evet & 47 & 28.7 \\
\hline Hayır & 117 & 71.3 \\
\hline \multicolumn{3}{|c|}{ Gazete-Dergi } \\
\hline Evet & 11 & 6.7 \\
\hline Hayır & 153 & 93.3 \\
\hline \multicolumn{3}{|c|}{ İnternet-Hizmet İçi Eğitim } \\
\hline Evet & 64 & 39.0 \\
\hline Hayır & 100 & 61.0 \\
\hline Toplam & 164 & 100 \\
\hline
\end{tabular}

"Biyolojik saldırı şekilleri nelerdir?" sorusunu öğrencilerin \%79.9'u “aerosol haline getirilmiş olan partiküllerin salınması”, \%78'inin "gıda-su kaynaklarının kontaminasyonu” ve \%72'sinin “çevresel kontaminasyon” olarak yanıtlamışlardır (Tablo 5).

Tablo 5. Biyolojik Saldırı Kullanım Şekilleri

\begin{tabular}{lcc}
\hline & Sayı & Yüzde \\
\hline $\begin{array}{l}\text { Aerosol Haline Getirilmiş Olan } \\
\text { Partiküllerin Salınması }\end{array}$ & & \\
Evet & 131 & 79.9 \\
Hayır & 33 & 20.1 \\
\hline Gıda-Su Kaynaklarının & & \\
Kontaminasyonu & & \\
Evet & 128 & 78.0 \\
Hayır & 36 & 22.0 \\
\hline Çevresel Kontaminasyon & & \\
Evet & 118 & 72.0 \\
Hayır & 46 & 28.0 \\
\hline
\end{tabular}

"Biyolojik ajanların vücuda giriş yolları nelerdir?" sorusuna öğrencilerin \%96.3'ü solunum yoluyla, \%68.9'u enjeksiyon yoluyla, \%87.2'si sindirim yoluyla, \%80.5'i göz yoluyla (konjonktiva), \%90.9'u deri yoluyla ve \%43.9'u üreme organları yoluyla girdiğini belirtmişlerdir (Tablo 6).

Tablo 7'de öğrencilerin biyolojik ajanların özelliklerine ilişkin bilgileri incelendiğinde; "biyolojik ajanların temin edilmesi, üretilmeleri ucuz, kolay ve hızlıdır" (\%51.8), "biyolojik ajanların maliyeti düşük olduğundan fakir ülkelerin atom bombasıdır" (\%44.5), "biyolojik ajanlar son derece toksiktir" (\%81.7), "biyolojik ajanların enfeksiyon yetenekleri fazladır ve salgına neden olur"

(\%84.7), "biyolojik ajanların teşhis ve tedavileri güçtür ve ilaçlara dirençlidirler” (\%57.9), “biyolojik ajanlar; uzun mesafelere (uçak, roket, balistik füze, top, mayın ve bomba vb. ile) ulaştırılabilir" (\%76.2), "biyolojik ajanlar; posta veya kargo yolu ile kullanılabilir” (\%50.0), "biyolojik ajanlar; hedeflenen bölgedeki havalandırma sistemleriyle, yiyecekler ya da sulara eklenerek kullanılabilir" (\%80.5), “biyolojik ajanlar rüzgârla beraber geniş alanlara yayılımı ile kitlesel ölümlere yol açabilir" (\%82.3) ifadelerine öğrenciler "evet” yanıtını vermişlerdir.

Tablo 6. Biyolojik Ajanların Vücuda Giriș Yolları

\begin{tabular}{lcc}
\hline & Sayı & Yüzde \\
\hline Solunum Yoluyla & 158 & 96.3 \\
Evet & 6 & 3.7 \\
Hayır & 113 & 68.9 \\
\hline Enjeksiyon Yoluyla & 51 & 31.1 \\
Evet & & \\
Hayır & 143 & 87.2 \\
\hline Sindirim Yoluyla & 21 & 12.8 \\
Evet & & \\
Hayır & 132 & 80.5 \\
\hline Göz Yoluyla (Konjonktiva) & 32 & 19.5 \\
Evet & & \\
Hayır & 149 & 90.9 \\
\hline Deri Yoluyla & 15 & 9.1 \\
Evet & & \\
Hayır & 72 & 43.9 \\
\hline Üreme Organları Yoluyla & 92 & 56.1 \\
Evet &
\end{tabular}

Tablo 8'de öğrencilerin biyolojik ajanlardan temizlenme ile ilgili bilgileri incelendiğinde öğrencilerin sorulara "evet" yanıtını verme oranları şu şekildedir; "Sağlık Bakanlığı, biyolojik ajanlara karşı korunma ve savunma tedbirlerinin alınmasından sorumludur” (\%64.6), "biyolojik ajan maruziyetinde C tipi elbise ile C düzeyi korunma uygulanır" (\%44.5), "biyolojik ajanla temas etmiş kişiler, sıcak sabunlu su veya antiseptik sabunla yıkanarak dekontamine edilir" (\%73.8), "biyolojik ajanla kontamine olmuş elbise, çamaşır ya da eşyalar kaynatılarak veya sabunlu deterjanlı su ile yıkanarak temizlenir" (\%73.2), "vücuttaki açık yaralar kapatılır" (\%79.9), "kullanılacak malzeme ve araçlar, sterilize edilir" (\%90.2), "biyolojik ajanla karşılaşan hastalara hekim istemine göre tedavi (aşı, serum ya da ilaç) uygulanır" (\%84.1), "yiyecek ve içecekler, temizleme işlemleri yapıldıktan sonra yenilebilir, içilebilir veya hastaların yemelerine, içmelerine izin verilir" (\%41.5), "biyolojik ajanlarla kontamine olduğu düşünülen bölgeler, temizleme maddeleri (kimyasal temizleyici ve kostik soda eriyiği gibi) ile dekontamine edilir" (\%60.4). 
Tablo 7. Öğrencilerin Biyolojik Ajanların Özelliklerine İlişkin Bilgileri (n=164)

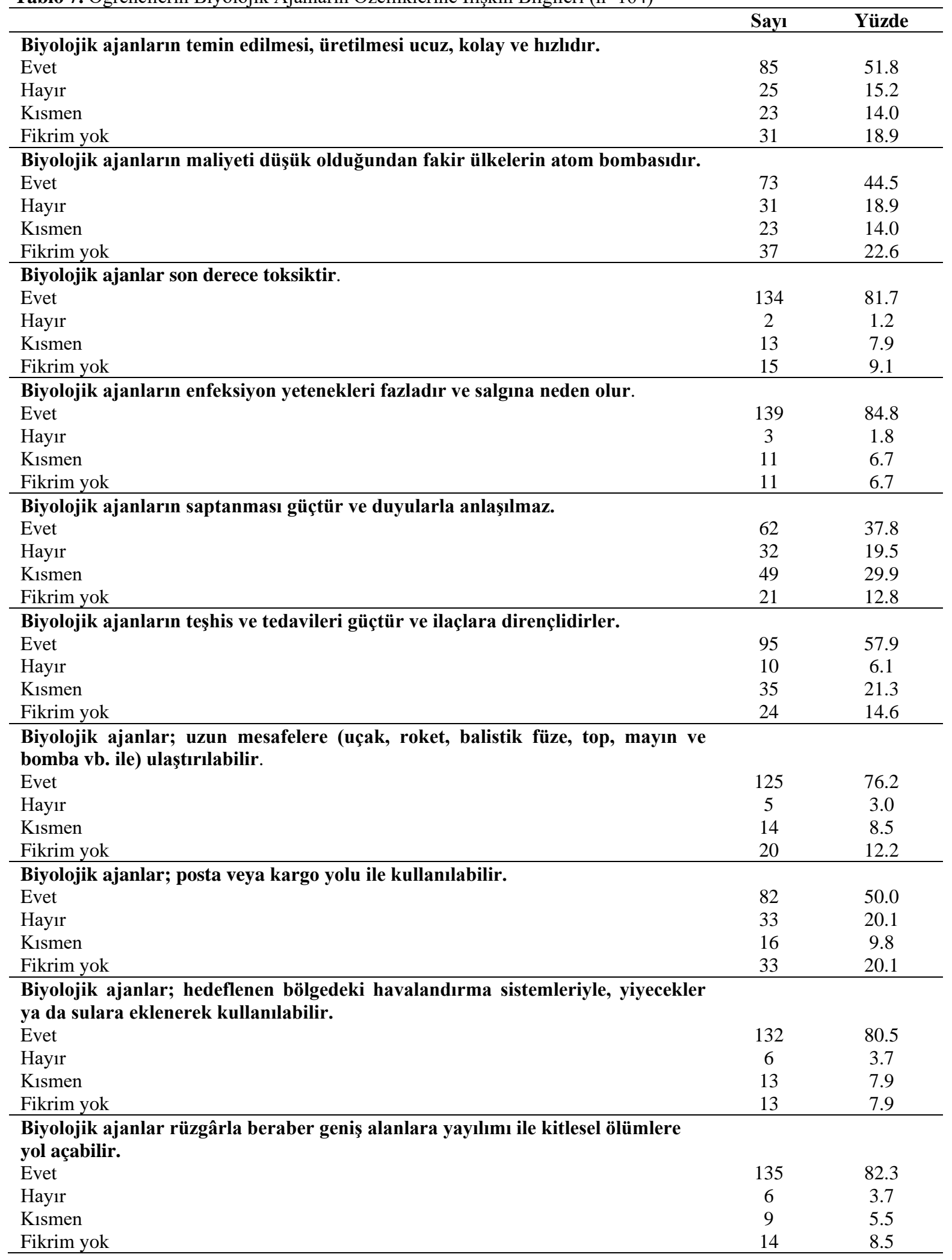


Tablo 8. Öğrencilerin Biyolojik Ajanlardan Temizlenme İle İlgili Bilgileri (n=164)

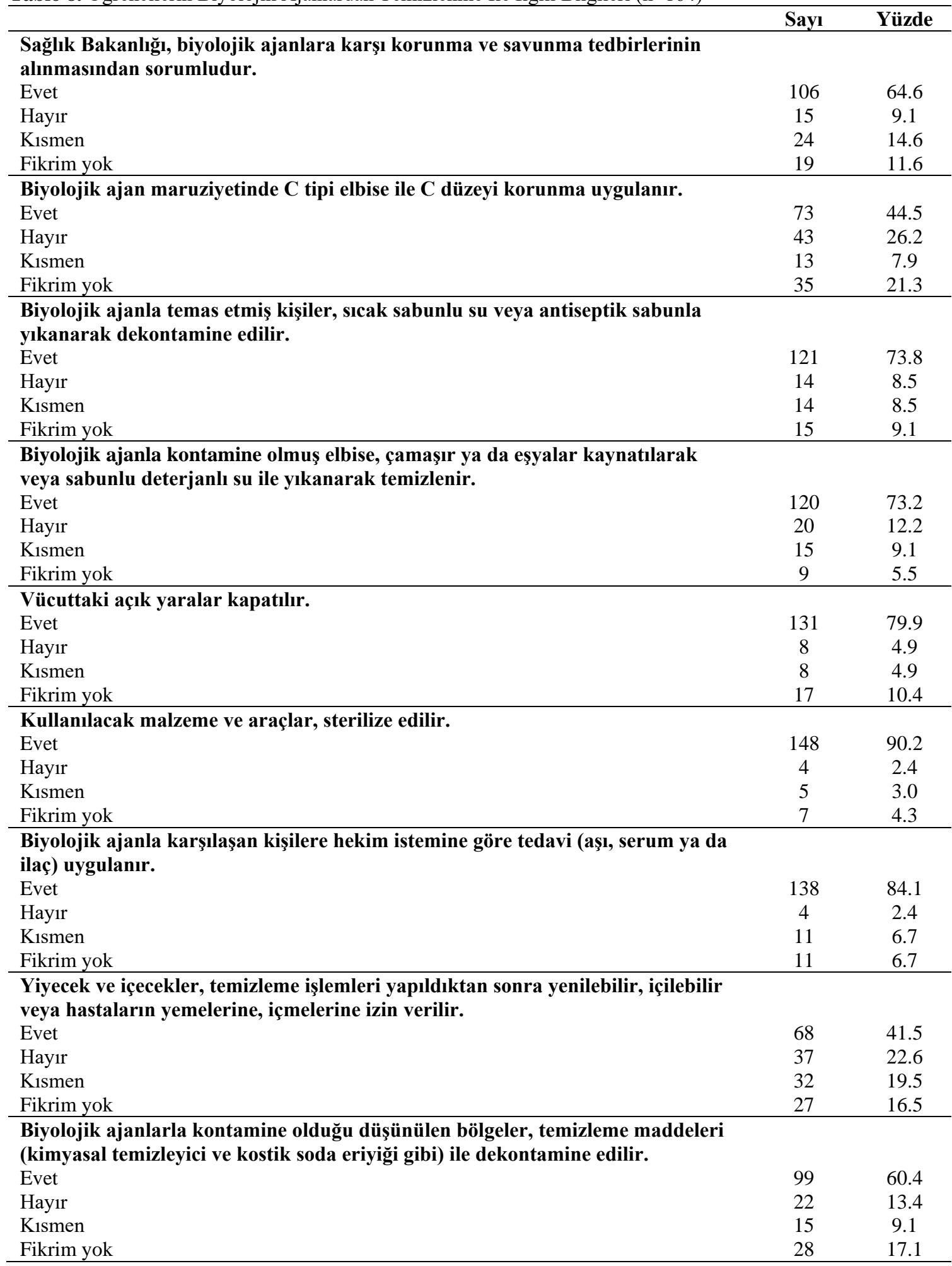

\section{TARTISSMA}

Araştırmaya katılan paramedik öğrencilerinin yaş ortalamasının $19.99 \pm 1.12$ (18-24 yaş aralığında) olduğu, öğrencilerin \%51.8'inin kadın, \%56.1'inin birinci sınıf, \%56.1'inin birinci öğretim, \%50.6'sının sağlık meslek lisesi mezunu, \%47'sinin şehirde yaşadığı, \%48.2'sinin gelirinin giderine denk olduğu belirlenmiş̧tir (Tablo 1). Sarıtaş ve ark. (7), acil hemşirelerinin biyoterörizm bilgi ve görüşleri üzerine yaptıkları çalışmada, hemşirelerin yaş ortalamasının $32.32 \pm 5.85$ (19-52 yaş) olduğunu, hemşirelerin \%62.4'ünün kadın, \%62.4'ünün uzun süredir şehirde yaşadığını, \%74.3'ünün gelir durumunun orta olduğunu ve \%51.4'ünün hemşirelik ön-lisans mezunu olduklarını bildirmişlerdir.

Paramediklerin ve acil çalışanlarının müdahale ettikleri kişinin biyolojik ajana maruz kalıp kalmadığını anlamak, belli ipuçlarını tanımak ve biyolojik ajanı uzaklaştırmak konusunda eğitimli olmaları oldukça önemlidir (4-6). Bu nedenle henüz mezun olmadan paramedik öğrencilerinin biyoterörizm ve biyolojik ajanlar konusunda bilgi sahibi 
olması eğitim-öğretim hedefleri arasında yer almalıdır. Araştırmaya katılan öğrencilerin \%45.5'i “biyoterörizmin ne olduğunu bildiğini”, \%45.1'i “biyoterörizm konusunda daha önce eğitim aldığını”, \%55.5'i "biyoterörizm konusunda eğitim almak istediğini”, \%60.4'ü "Türkiye'nin biyoterörizm konusunda risk taşıdığını", \%47.6's1 “Türkiye'nin biyoterörizm konusunda tehlike yaşama durumu konusunda fikri olmadığını", \%69.5'i "biyoterörizmde paramediklerin rol ve sorumluluklarının bulunduğunu”, \%64.6'sı “biyoterörizmle saldırı için çalışma yapan ülkelerin olduğunu" ve \%37.2'si "biyoterörizmle saldırı ihtimaline karşı diğer ülkelerin önlem aldığını" ifade etmişılerdir (Tablo 2). Sarıtaş ve ark. (7) ise çalışmalarında, hemşirelerin \%57.8'inin "biyoterörizm kavramını bildiğini”, \%84.3'ünün "biyoterörizm konusunda eğitim almak istediğini”, \%93.9’unun “Türkiye’nin biyoterörizm konusunda risk taşıdığını”, \%89.9'unun “Türkiye'nin biyoterörizm konusunda tehlike yaşadığını belirttiğini”, \%96.1'inin "biyoterörizmle saldırı için çalışma yapan ülkelerin olduğunu" ve \%99.9'unun "biyoterörizmle saldırı ihtimaline karşı diğer ülkelerin önlem aldığını" ifade ettiklerini bildirmiştir. Yine Polonya'da hemşireler üzerinde yapılan "biyoterörizm farkındalıkları" isimli çalışmada, katılımcıların \%78'inin Polonya'da biyoterörizm tehdidi olduğunu ifade ettikleri bildirilmiştir (8). Çalışmalar arasındaki farklılıkların katılımcıların öğrenci paramedik ve çalışan hemşire grubu olmasından kaynaklandığı düşünülmektedir.

Araştırmaya katılan öğrencilerin \%34.8'inin okuldanderslerde, \%28.7'sinin TV-radyo, \%6.7'sinin gazetedergi, \%39.0 internet-hizmet içi eğitim ile biyoterörizmin ne olduğunu öğrendikleri belirlenmiştir (Tablo 4). Sarıtaş ve ark. (7) çalışmasında, biyoterörizm kavramını acil hemşirelerinin \%14.1'inin okuldan-derslerden, \%30.3’ünün TV-radyodan, \%20.2'sinin gazete-dergiden ve \%35.4'ünün internet-hizmet içi eğitimden öğrendiklerini bildirmișlerdir.

Az miktarda kullanılan bir biyolojik ajanla bile büyük kitleler etkilenebilir. Maruz kalan kişilerde fiziksel ve yarattığı panikle birlikte kalıcı ruhsal problemler gelişebilir. Hatta ileriki zamanlarda biyoterörizmin panik yaratmak için kullanılacağı düşünülmektedir. Kitle imha silahları arasında biyolojik ajanların (silahların) en maliyetsiz saldırı olduğu ve bu nedenle ekonomik anlamda fakir ülkelerin "atom bombası" olarak adlandırılmaktadır. Kuluçka sürelerinin olması nedeniyle biyolojik ajan saldırılarının anlaşılması ve tespiti zordur (9). Oluşturulmuş küçük bir sanayi tesisinde, laboratuvarda ve aşı üretim enstitülerinde bile biyolojik silah üretilebilir $(10,11)$. Biyolojik savaş ajanlarının transportu basittir ve düşük bütçelerle çok miktarlarda üretmek mümkündür. Genel güvenlik sistemleri tarafından saptanmaları güçtür ve kolayca taşınabilirler (12). Biyoterörizmin terörist gruplar tarafından çok tercih edilmesinin nedeni; biyolojik silahların sadece canlılarda (insan, hayvan, bitki gibi) morbitite ve mortaliteye neden olması ve bu sayede saldırıyı yapanın gizlenmesidir (13). $\mathrm{Bu}$ araştırmada öğrencilerin biyolojik ajanların özelliklerine ilişkin bilgileri incelendiğinde; "Biyolojik ajanların temin edilmesi, üretilmeleri ucuz, kolay ve hızlıdır" (\%51.8), "biyolojik ajanların maliyeti düşük olduğundan fakir ülkelerin atom bombasıdır" (\%44.5), "biyolojik ajanlar son derece toksiktir" (\%81.7), "biyolojik ajanların enfeksiyon yetenekleri fazladır ve salgına neden olur" (\%84.7), "biyolojik ajanların saptanması güçtür ve duyularla anlaşılmaz" (\%37.8), "biyolojik ajanların teşhis ve tedavileri güçtür ve ilaçlara dirençlidirler” (\%57.9), "biyolojik ajanlar; uzun mesafelere (uçak, roket, balistik füze, top, mayın ve bomba vb. ile) ulaştırılabilir” (\%76.2), "biyolojik ajanlar; posta veya kargo yolu ile kullanılabilir" (\%50.0), "biyolojik ajanlar; hedeflenen bölgedeki havalandırma sistemleriyle, yiyecekler ya da sulara eklenerek kullanılabilir" (\%80.5), "biyolojik ajanlar rüzgârla beraber geniş alanlara yayılımı ile kitlesel ölümlere yol açabilir" (\%82.3) ifadelerine öğrenciler “evet” yanıtını vermişlerdir (Tablo 7). Araştırma sonuçlarının literatür bilgisiyle paralel sonuçlar olduğu tespit edilmiştir.

Biyolojik savaş ajanlarının çoğu ssıya ve ortam koşullarına karşı dayanıksızdır. Dolayısıyla kontamine olmuş eşyaların yaklaşık $10 \mathrm{dk}$. kaynatılması, biyolojik ajanlarla kirletildiğinden şüphe edilen bölgeler ve nesnelerin formaldehit ya da $\% 5 \mathrm{NaOCl}$ (1/10 oranında sulandırılmış) ile arındırılması mümkündür. Ayrıca arındırma işleminde sabunlu su da kullanılabilir (14-16). Ilık veya soğuk alanda müdahale eden acil tıp teknikerleri müdahale sırasında $\mathrm{C}$ düzeyi koruma sağlayarak ve $\mathrm{C}$ tipi elbise giyerek (disposable maske, gözlük, eldiven, önlük, el yıkama) acil bakım vermeleri yeterli olacaktır $(15,17,18)$. $\mathrm{Bu}$ bilgiler çerçevesinde öğrencilerin biyolojik ajanlardan temizlenme ile ilgili bilgileri incelendiğinde "Sağlık Bakanlığı, biyolojik ajanlara karşı korunma ve savunma tedbirlerinin alınmasından sorumludur" (\%64.6), "biyolojik ajan maruziyetinde C tipi elbise ile C düzeyi korunma uygulanır" (\%44.5), "biyolojik ajanla temas etmiş kişiler, sıcak sabunlu su veya antiseptik sabun ile y1kanarak dekontamine edilir" (\%73.8), "biyolojik ajanla kontamine olmuş elbise, çamaşır ya da eşyalar kaynatılarak veya sabunlu deterjanlı su ile yıkanarak temizlenir" (\%73.2), "vücuttaki açık yaralar kapatılır" (\%79.9), "kullanılacak malzeme ve araçlar, sterilize edilir” (\%90.2), "biyolojik ajanla karşılaşan hastalara doktor ordırına göre tedavi (aşı, serum ya da ilaç) uygulanır” (\%84.1), “yiyecek ve içecekler, temizleme işlemleri yapıldıktan sonra yenilebilir ve içilebilir veya hastaların yemelerine ve içmelerine müsaade edilir” (\%41.5), "biyolojik ajanlar ile kontamine olduğu düşünülen bölgeler, temizleme maddeleri (kimyasal temizleyici ve kostik soda eriyiği gibi) ile dekontamine edilir" (\%60.4) ifadelerine öğrenciler "evet” yanıtını vermişlerdir (Tablo 8).

\section{SONUC VE ÖNERILER}

$\mathrm{Bu}$ araştırma sonucunda öğrencilerin biyoterörizm ve biyolojik ajanlar konusunda bilgi ve görüşleri literatür bilgileri ile paralel olsa da; çalışma yaşamında vakalarla bire bir karşılaşacakları göz önünde bulundurulduğunda istenilen seviyede değildir.

Kitle imha silahları (nükleer, kimyasal, biyolojik ve radyolojik) arasında yer alan biyolojik silahların dünya ülkeleri arasında kullanımı yaygınlaşmaya devam etmektedir. Bu nedenle; paramedik adaylarına eğitimögretim dönemlerinde birinci sınıfta verilen biyolojik silah yaralanmalarında acil bakım ve müdahale konuları belli periyotlarda tekrarlanmalı ve demonstrasyon 
uygulamaları yapılmalıdır. Ayrıca sağlık personellerine (hekim, hemşire, paramedik, acil tıp teknisyeni vb.) biyoterörizm ve biyolojik ajanlarda korunma, tanıma ve müdahale konusunda hizmet içi eğitimler verilmelidir.

\section{KAYNAKLAR}

1. Venkatesh S, ZiadMemish A. Bioterrorism a new challenge for public health. International Journal of Antimicrobial Agents. 2003; 21(2): 200-6.

2. Yüksel $O$, Erdem R. Biyoterörizm ve sağlik. Hacettepe Sağlık İdaresi Dergisi. 2016; 19(2): 203-22.

3. Erkekoğlu P, Koçer-Gümüşel B. Biyolojik Savaş Ajanları: Tarihçeleri, Patofizyolojileri, Tanıları, Tedavileri ve Önlemler. FABAD J Pharm Sci. 2018; 43(2): 81-111.

4. Hick JL, Hanfling D, Burstein JL, Markham J, Macintyre AG, Barbera JA. Protective equipment for health care facility decontamination personnel: Regulations, risks, and recommendations. Annemerg Med. 2003; 42(3): 370-80.

5. Carsus WS. Biological war fare threats in perspective. Crit Rew Microbiol. 1998; 24(3): 149-55.

6. Christopher GW, Cieslak TJ, Pavin JA, Eitzen EM. Biological war fare threats in perspective. JAMA. 1997; 278(5): 412-7.

7. Sarıtaş ÇT, Kızıl AB, Sarıtaş S. Acil servis hemşirelerinin biyoterörizm konusundaki bilgi ve görüşleri. Bozok Tıp Dergisi. 2013; 3(2): 29-36.

8. Renn-Żurek A, Lopacińska I, Tokarski Z, Denys A. Assessment of Bioterrorism Awareness in a Group of Nurses. Micro Medicine. 2015; 3(1): 20-5.

9. Kiremitçi İ. Küresel Boyutta Biyolojik Terör Tehdidi. Savunma Bilimleri Dergisi. 2014; 13(2): 27-58.

10. Hüşan UH. Biyolojik Terör Riskine Karşı Tıbbi Müdahalenin Etkinliğinin İrdelenmesi ve Yerel Yanıtın Geliştirilmesi [Doktora Tezi]. Çanakkale: Çanakkale On Sekiz Mart Üniversitesi Fen Bilimleri Enstitüsü; 2010.

11. Serinken M, Kutlu SS. Biyoterörizm ve Şarbon. Türkiye Acil Tıp Dergisi. 2009; 9(4): 185-90.

12. Kılıç S. Biyolojik Silahlar ve Biyoterörizm. Türk Hijyen ve Deneysel Biyoloji Dergisi. 2006; 63(1): 120.

13. Özgür S. Soğuk Savaş ve Sonrası Dönemde Kitle İmha Silahları ve Silahsızlanma Çabaları [Yüksek Lisans Tezi]. Isparta: Süleyman Demirel Üniversitesi Sosyal Bilimler Enstitüsü; 2006.

14. Arnon SS, Schechter R, Inglesby TV, Henderson DA, Bartlett JG, Ascher MS, et, al. Botulinum Toxin as a Biological Weapon: Medical and Public Health Management. JAMA. 2001; 285(8): 1059-70.

15. Woods JB, Darling RG, Dembek ZF, Carr BK, Cieslak TJ, Lawler JV et al., editors. Biological Toxins. In: USAMRIID's Medical Management of Biological Casualties Handbook. 6th ed. Fort Detrick Frederick, Maryland: U.S. Army Medical Research Institute of Infectious Diseases; 2005. p. 85-101.

16. Sidell FR, Takafuji ET, Franz DR, editors. Medical Aspects of Chemical and Biological Warfare. In: Textbook of Military Medicine. Washington, DC: Office of the Surgeon General; 1997. p. 603-76.
17. Patocka J, Splino M. Botulinum Toxin: From Poison to Medicinal Agent. The ASA Newsletter. 2002; 88: 14-24.

18. White SM. Chemical and biological weapons. Implications for anaesthesia and intensive care. $\mathrm{Br} \mathrm{J}$ Anaesth. 2002; 89(2): 306-24. 